\title{
Determinan Faktor Prediabetes di Kota Jambi Tahun 2019
}

\author{
Sovia $^{1}$, Netha Damayantie ${ }^{2}$, Nur Insani ${ }^{3 *}$ \\ 1,2,3 Jurusan Keperawatan Politeknik Kesehatan Kemenkes Jambi \\ Jl. Dr. Tazar. No.05 Kel.Buluran Kenali, Kec. Telanaipura, Jambi, 36123, Indonesia \\ *Correspondence email: nurinsani@poltekkesjambi.ac.id
}

\begin{abstract}
Abstrak. Prediabetes merupakan kondisi ambang dari penyakit diabetes. Keadaan ini sering tidak diketahui atau dipahami oleh masyarakat sehingga angka kejadiannya tidak terdokumentasikan. Penelitian ini bertujuan untuk mengidentifikasi kejadian Prediabetes dan faktor risikonya. Desain penelitian adalah cross sectional dengan populasi sebanyak 260 dan jumlah sampel sebanyak 169 orang yang diambil secara purposive sampling. Penelitian ini dilakukan di salah satu institusi pendidikan kesehatan di Kota Jambi pada bulan Oktober dan November 2019. Pengumpulan data dengan menggunakan kuisioner dan pemeriksaan kadar gula darah puasa. Analisis data menggunakan proporsi frekuensi, Chi-Square, dan regresi logistik. Hasil penelitian menunjukkan kejadian prediabetes sebesar $21,9 \%$ dan faktor yang mempengaruhinya adalah umur $(p=0,038, \mathrm{OR} 0,423,95 \% \mathrm{CI}$ 0,185-0,966), olahraga ( $p=0,002$, OR 0,228, 95\% CI 0.083-0,626), perilaku merokok ( $p=0,003$, OR 3,106, 95\% CI 1,425-6,770), dan status gizi $(p=0,028)$. Berdasarkan hasil penelitian direkomendasikan untuk menggalakkan kegiatan Gerakan Masyarakat Sehat di Kota Jambi dan perlu diadakannya kegiatan Posbindu secara rutin setiap bulannya.
\end{abstract}

Kata kunci: Prediabetes; Umur, Olahraga, Perilaku Merokok, Status Gizi

Abstract. Prediabetes is a threshold condition of diabetes. This situation is often unknown or understood by the public so the incidence rate is undocumented. This research aims to identify the incidence of Prediabetes and its risk factors. The design of the study was cross sectional with a population of 260 and a sample count of 169 people taken purposive sampling. This research was conducted at one of the health education institutions in Jambi City in October and November 2019. Data collection using questionnaires and fasting blood sugar levels. Data analysis uses frequency proportions, Chi-Square, and logistic regression. The results showed a prediabetes incidence of $21.9 \%$ and factors affecting it were age ( $p=0.038$, OR 0.423, 95\% CI 0.185-0.966), exercise ( $p=0.002$, OR 0.228, 95\% CI 0.083-0.626), smoking behavior ( $p=0.003$, OR 3,106, 95\% CI 1,425-6,770), and nutritional status $(p=0.028)$. Based on the results of research recommended to promote the activities of Healthy Community Movement in Jambi City and the need to hold posbindu activities regularly every month.

Keywords: Prediabetes; Age; Exercise; Smoking Behavior; Nutritional Status

\section{PENDAHULUAN}

Kejadian penyakit tidak menular di Indonesia mengalami peningkatan setiap tahunnya, satu diantaranya adalah penyakit diabetes melitus. Menurut Riset Kesehatan Dasar Indonesia, prevalensi diabetes sebesar $1,1 \%$ pada tahun 2013 dan $1,5 \%$ pada tahun 2018 (Balitbangkes Kemenkes RI, 2018). Keadaan ini dapat dicegah dengan mengetahui kadar glukosa darah sedini mungkin pada seseorang yang mempunyai faktor risiko diabetes.

Menurut Basina, Higuera, dan Huffman (2018), penyakit diabetes umumnya dimulai dari kondisi prediabetes. Prediabetes merupakan ambang diabetes, yaitu suatu kondisi metabolisme yang ditandai dengan kadar glukosa darah lebih tinggi dari normal tetapi belum cukup tinggi untuk digolongkan sebagai diabetes. Kadar glukosa darah puasa antara 100-125 mg/dL (5,67,0 $\mathrm{mmol} / \mathrm{L}$ ) disebut dengan prediabetes atau impaired fasting glucose (Mayo Clinic Staff, 2020).

Leontis dan Fischl (2020) menjelaskan bahwa prediabetes berkembang saat tubuh mulai kesulitan menggunakan hormon insulin. Insulin diperlukan untuk mengangkut glukosa (yang digunakan tubuh untuk energi) ke dalam sel melalui aliran darah. Pada prediabetes, tubuh tidak menghasilkan cukup insulin atau tidak menggunakannya dengan baik (disebut resistensi insulin).

Prediabetes tidak menunjukkan tanda gejala, sehingga sebagian besar individu tidak mengetahui kondisi prediabetesnya. Hal ini menyebabkan prevalensi prediabetes tidak dapat diketahui secara pasti. CDC (2019) melaporkan bahwa dari 88 juta penduduk dewasa di Amerika Serikat, 1 dari 3 orang mengalami prediabetes. Hasil penelitian Soewondo dan Pramono (2011) menunjukkan prevalensi prediabetes pada daerah perkotaan di 33 propinsi di Indonesia sebesar 10,2\%, prevalensi diabetes 5,7\%. Sedangkan penelitian Sovia, Rekawati, dan Kuntarti (2013) menemukan sebesar 47,4\% kelompok umur dewasa mengalami prediabetes.

Faktor risiko prediabetes dan faktor risiko diabetes sama dengan diabetes melitus tipe 2, karena prediabetes merupakan tahap awal untuk menjadi diabetes melitus. Scalpi (2011), Bauch (2016), dan CDC (2020) menyatakan faktor-faktor risiko dari prediabetes adalah umur $\geq 45$ tahun, terdapat riwayat keluarga dengan diabetes melitus, overweight (BMI > 25), aktivitas fisik tidak aktif atau olahraga kurang dari 3 kali perminggu, riwayat diabetes gestasional. NDSS (2020) menjelaskan bahwa salah satu faktor risiko prediabetes adalah kelebihan berat badan, terutama individu yang memiliki 
berat badan berlebih di sekitar garis pinggang (yaitu: lebih dari $94 \mathrm{~cm}$ untuk pria dan lebih dari $80 \mathrm{~cm}$ untuk wanita).

Kondisi prediabetes harus mendapatkan perhatian dan perawatan agar tidak berdampak pada penderitanya. Prediabetes yang tidak mendapatkan intervensi yang tepat akan berkembang menjadi diabetes tipe 2 dalam waktu 5 tahun (CDC, 2019). Sementara itu, Basina, Higuera, dan Huffman (2018) menyatakan bahwa prediabetes bersifat reversible, akan tetapi dapat menjadi diabetes tipe 2 dalam waktu 10 tahun jika tidak melakukan perubahan gaya hidup.

Prediabetes menimbulkan dampak yang tidak baik bagi kesehatan individu, dan memicu timbulnya masalah kesehatan lain. Abraham dan Caroline (2013) menyatakan bahwa gula darah puasa $\geq 100 \mathrm{gr} / \mathrm{dL}$ akan memicu terjadinya diabetes mellitus, penyakit kardiovaskuler, dan kematian. Pendapat lain menjelaskan bahwa prediabetes yang dialami oleh seseorang akan menyebabkan risiko penyakit jantung, penyakit pembuluh darah perifer, dan stroke sebesar $50 \%$ dari pada orang yang memiliki kadar glukosa darah normal (Greene, Merendino, dan Jibrin, 2009).

American Diabetes Association (ADA) mengatakan bahwa perubahan gaya hidup efektif dalam mencegah diabetes tipe 2 setelah seseorang didiagnosis dengan prediabetes. Beberapa hal yang direkomendasikan untuk penderita prediabetes adalah pengaturan makan (diit), latihan fisik, menurunkan berat badan dalam batas normal, dan penggunaan Metformin bagi individu yang berisiko tinggi (Leontis dan Fischl, 2020).

Pengenalan prediabetes sangat penting, mengingat risiko perkembangan menjadi diabetes. Mengidentifikasi individu dengan prediabetes menawarkan kesempatan untuk mengubah risiko mereka sehingga dapat mencegah diabetes. Pengawasan ketat terhadap peningkatan prevalensi prediabetes sangat penting untuk memproyeksikan beban diabetes di masa mendatang dan sumber daya yang akan dibutuhkan untuk memerangi diabetes di masa mendatang.

\section{METODE}

Jenis penelitian adalah deskriptif analitik dengan rancangan cross sectional. Variabel independen yang diteliti adalah umur, genetik, komposisi keluarga, kebiasaan olahraga, perilaku merokok dan status gizi. Variabel dependen adalah kejadian prediabetes. Lokasi penelitian di salah satu institusi pendidikan kesehatan di Kota Jambi dan dilaksanakan pada bulan Juni sampai dengan November 2019. Populasi penelitian sebanyak 260 orang dengan sampel berjumlah 169 orang yang diambil dengan cara purposive sampling.

Pengumpulan data menggunakan kuisioner untuk variabel independen, dan glukometer untuk variabel dependen. Kuisioner diujicobakan dulu sebelum digunakan. Alat glucometer yang digunakan sebanyak 2 buah dalam kondisi baru dengan merek Autocheck. Pengolahan dan analisis data menggunakan sistem komputerisasi Program SPSS Versi 24 for windows. Analisis data terdiri dari: analisis univariat untuk mengetahui distribusi frekuensi dan proporsi dari variabel independen, analisis bivariat menggunakan ChiSquare untuk mengetahui hubungan antara variabel independen dan dependen, serta analisis multivariat menggunakan regresi logistik untuk mengetahui faktor yang paling dominan.

\section{HASIL}

\section{Gambaran Kejadian Prediabetes}

Tabel 1. Distribusi Frekuensi Kejadian Prediabetes di Institusi Pendidikan Kesehatan X Kota Jambi Tahun 2019

\begin{tabular}{lcc}
\hline \multicolumn{1}{c}{ Kejadian Prediabetes } & f & $\%$ \\
\hline Prediabetes & 37 & 21,9 \\
Bukan Prediabetes & 132 & 78,1 \\
Total & 169 & 100 \\
\hline
\end{tabular}

Pada tabel diatas dapat diketahui bahwa kejadian prediabetes di Poltekkes Kemenkes Jambi tahun 2019 sebesar $21,9 \%$.

\section{Gambaran Faktor Risiko Prediabetes}

Tabel 2. Distribusi Frekuensi Responden Berdasarkan Umur di Institusi Pendidikan Kesehatan X Kota Jambi Tahun 2019

\begin{tabular}{lcc}
\hline \multicolumn{1}{c}{ Faktor Risiko Prediabetes } & f & $\%$ \\
\hline Umur yang berisiko (> 45 tahun) & 68 & 40,2 \\
Umur tidak berisiko ( $\leq 45$ tahun) & 101 & 59,8 \\
Total & 169 & 100 \\
\hline
\end{tabular}

Tabel 2 menunjukkan bahwa sebagian besar responden berada pada kelompok umur tidak berisiko ( $\leq 45$ tahun), yaitu sebanyak $59,8 \%$.

Tabel 3. Distribusi Frekuensi Responden Berdasarkan Genetik di Institusi Pendidikan Kesehatan X Kota Jambi Tahun 2019

\begin{tabular}{llcc}
\hline \multicolumn{1}{c}{ Faktor Risiko Prediabetes } & $\mathrm{f}$ & $\%$ \\
\hline a. Mempunyai genetik diabetes & 36 & 21,3 \\
b. Tidak mempunyai genetik & 133 & 78,7 \\
$\quad$ diabetes & 169 & 100 \\
Total & 169 & \\
\hline
\end{tabular}

Berdasarkan tabel 3 diketahui bahwa sebagian besar responden tidak memiliki riwayat genetik diabetes dalam keluarga.

Tabel 4. Distribusi Frekuensi Responden Berdasarkan Komposisi Keluarga, Kebiasaan Olahraga, Perilaku Merokok, dan Status Gizi di Institusi Pendidikan Kesehatan X Kota Jambi Tahun $2019(n=169)$

\begin{tabular}{|c|c|c|}
\hline Faktor Risiko Prediabetes & $\mathrm{F}$ & $\%$ \\
\hline Komposisi Keluarga & & \\
\hline a. Anggota keluarga $<5$ orang & 113 & 66,9 \\
\hline b. Anggota keluarga $\geq 5$ orang & 56 & 33,1 \\
\hline
\end{tabular}

Kebiasaan Olahraga 


\begin{tabular}{lccc}
\hline a. $\quad<3$ kali seminggu & 151 & 89,3 \\
b. $\quad \geq 3$ kali seminggu & 18 & 10,7
\end{tabular}

Perilaku Merokok

a. Mempunyai kebiasaan merokok $42 \quad 24,9$

b. Tidak mempunyai kebiasaan $\quad 127 \quad 75,1$ merokok

Status gizi

\begin{tabular}{|c|c|c|}
\hline Gizi kurang & 4 & 2,4 \\
\hline Gizi normal & 78 & 46,2 \\
\hline Gizi lebih & 87 & 51,5 \\
\hline
\end{tabular}

Tabel 4 memperlihatkan bahwa sebagian besar responden memiliki jumlah komposisi keluarga kurang dari 5 orang $(66,9 \%)$, mempunyai kebiasaan olahraga kurang dari 3 kali seminggu $(89,3 \%)$, tidak mempunyai kebiasaan merokok $(75,1 \%)$, dan memiliki status gizi lebih $(51,5 \%)$.

Berdasarkan hasil analisis univariat diketahui distribusi frekuensi faktor risiko prediabetes yang dimiliki oleh sebagian besar pegawai di Institusi Pendidikan Kesehatan X Kota Jambi, antara lain: kebiasaan olahraga yang kurang dari 3 kali perminggu, perilaku merokok, dan status gizi lebih. Selanjutnya dilakukan analisis bivariat untuk melihat hubungan antara faktor risiko dengan kejadian prediabetes.

Hubungan Faktor Risiko dengan Kejadian Diabetes

Tabel 5. Hubungan Faktor Risiko dengan Kejadian Prediabetes Pada Pegawai di Institusi Pendidikan Kesehatan X Kota Jambi Tahun 2019

\begin{tabular}{|c|c|c|c|c|c|c|c|c|}
\hline \multirow{3}{*}{ Faktor Risiko } & \multicolumn{4}{|c|}{ Kejadian Prediabetes } & & & \multirow{3}{*}{$\begin{array}{c}\text { OR } \\
95 \% \mathrm{CI}\end{array}$} & \multirow{3}{*}{$\mathrm{p}$-value } \\
\hline & \multicolumn{2}{|c|}{ Prediabetes } & \multicolumn{2}{|c|}{$\begin{array}{c}\text { Bukan } \\
\text { Prediabetes }\end{array}$} & \multicolumn{2}{|c|}{ Total } & & \\
\hline & $\mathrm{F}$ & $\%$ & $\mathrm{~F}$ & $\%$ & $\mathrm{~F}$ & $\%$ & & \\
\hline \multicolumn{9}{|l|}{ Umur } \\
\hline $\begin{array}{l}\text { 1. Berisiko } \\
\text { (> } 45 \text { tahun) }\end{array}$ & 17 & 25 & 51 & 75 & 68 & 100 & \multirow[t]{3}{*}{$\begin{array}{c}1,350 \\
(0,647-2,816)\end{array}$} & \multirow[t]{3}{*}{0,423} \\
\hline $\begin{array}{l}\text { 2. Umur tidak berisiko } \\
\text { ( } \leq 45 \text { tahun) }\end{array}$ & 20 & 19,8 & 81 & 80,2 & 101 & 100 & & \\
\hline Total & 37 & 21,9 & 132 & 78,1 & 169 & 100 & & \\
\hline \multicolumn{9}{|l|}{ Genetik Diabetes } \\
\hline 1. Ada & 8 & 22,2 & 28 & 77,8 & 36 & 100 & \multirow{3}{*}{$\begin{array}{c}1,025 \\
(0,422-2,488)\end{array}$} & \multirow[t]{3}{*}{0,957} \\
\hline 2. Tidak ada & 29 & 21,8 & 104 & 78,2 & 133 & 100 & & \\
\hline Total & 37 & 21,9 & 132 & 78,1 & 169 & 100 & & \\
\hline \multicolumn{9}{|l|}{ Komposisi Keluarga } \\
\hline $\begin{array}{l}\text { 1. Jumlah anggota keluarga }<5 \\
\text { orang }\end{array}$ & 24 & 21,2 & 89 & 78,8 & 113 & 100 & \multirow[t]{2}{*}{$\begin{array}{c}0,892 \\
(0,414-1,920)\end{array}$} & \multirow[t]{2}{*}{0,770} \\
\hline $\begin{array}{l}\text { 2. Jumlah anggota keluarga } \geq 5 \\
\text { orang }\end{array}$ & 13 & 23,2 & 43 & 76,8 & 56 & 100 & & \\
\hline Total & 37 & 21,9 & 132 & 78,1 & 169 & 100 & & \\
\hline \multicolumn{9}{|l|}{ Kebiasaan Olahraga } \\
\hline 1. Olahraga $<3$ hari perminggu & 28 & 18,5 & 123 & 81,5 & 151 & 100 & \multirow{3}{*}{$\begin{array}{c}0,228 \\
(0,083-0,626)\end{array}$} & \multirow[t]{3}{*}{$0,002 *$} \\
\hline 2. Olahraga $\geq 3$ hari perminggu & 9 & 50,0 & 9 & 50,0 & 18 & 100 & & \\
\hline Total & 37 & 21,9 & 132 & 78,1 & 169 & 100 & & \\
\hline \multicolumn{9}{|l|}{ Perilaku Merokok } \\
\hline 1. Mempunyai kebiasaan merokok & 16 & 38,1 & 26 & 61,9 & 42 & 100 & \multirow{3}{*}{$\begin{array}{c}3,106 \\
(1,425-6,770)\end{array}$} & \multirow[t]{3}{*}{$0,003^{*}$} \\
\hline $\begin{array}{l}\text { 2. Tidak mempunyai kebiasaan } \\
\text { merokok }\end{array}$ & 21 & 16,5 & 106 & 83,5 & 127 & 100 & & \\
\hline Total & 37 & 21,9 & 132 & 78,1 & 169 & 100 & & \\
\hline \multicolumn{9}{|l|}{ Status Gizi } \\
\hline 1. Gizi kurang & 0 & 0 & 4 & 100 & 4 & 100 & - & \multirow[t]{4}{*}{$0,028 *$} \\
\hline 2. Gizi normal & 11 & 14,1 & 67 & 85,9 & 78 & 100 & & \\
\hline 3. Gizi lebih & 26 & 29,9 & 61 & 70,1 & 87 & 100 & & \\
\hline Total & 37 & 21,9 & 132 & 78,1 & 169 & 100 & & \\
\hline
\end{tabular}

* bermakna pada $\alpha=0,05$

Berdasarkan tabel 5 dapat diketahui bahwa terdapat tiga faktor yang tidak mempunyai hubungan bermakna dengan kejadian prediabetes (nilai $\mathrm{p}>0,05$ ), antara lain: umur, genetik, dan komposisi keluarga. Namun, tabel 5 juga memperlihatkan ada tiga faktor yang memiliki hubungan yang signifikan dengan kejadian prediabetes di Institusi Pendidikan Kesehatan X
Kota Jambi karena memiliki nilai $\mathrm{p}<0,005$, yaitu: kebiasaan olahraga, perilaku merokok, dan status gizi.

Individu yang melakukan olahraga $\geq 3$ kali perminggu mempunyai peluang sebesar 0,228 kali untuk mencegah prediabetes dibandingkan individu yang berolahraga $<3$ kali perminggu. Sementara itu, seorang 
perokok berpeluang sebesar 3,1 kali untuk mengalamai prediabetes dibandingkan yang tidak merokok.

\section{Faktor Risiko Yang Dominan dengan Kejadian Diabetes}

Tabel 6. Hasil Pemodelan Multivariat antara antara Kebiasaan Olahraga, Perilaku Merokok, dan Status Gizi Dengan Kejadian Prediabetes Pada Pegawai di Institusi Pendidikan Kesehatan X Kota Jambi Tahun $2019(\mathrm{n}=169)$

\begin{tabular}{|c|c|c|c|c|}
\hline \multirow[t]{2}{*}{ Variabel } & \multirow[t]{2}{*}{ B } & \multirow[t]{2}{*}{$P$} & \multirow[t]{2}{*}{$O R$} & $\begin{array}{l}\text { 95\% C.Ifor } \\
\text { EXP(B) }\end{array}$ \\
\hline & & & & Lower Upper \\
\hline Status gुzíl & 0,858 & $0,041^{*}$ & 2,357 & $1,035 \quad 5,372$ \\
\hline Perilakumerokok & $-0,947$ & $0,025^{*}$ & 0,388 & $0,170 \quad, 887$ \\
\hline Kebilassann olahraga & 1,389 & $0,012^{*}$ & 4,012 & $1,361 \quad 11,822$ \\
\hline Constant & $-0,018$ & 0,975 & 0,982 & \\
\hline
\end{tabular}

Berdasarkan tabel di atas diketahui bahwa variabel yang berpengaruh terhadap kejadian prediabetes pada pegawai di Institusi Pendidikan Kesehatan X Kota Jambi adalah: status gizi, perilaku merokok, dan kebiasaan olahraga. Selanjutnya juga diketahui, variabel yang paling besar pengaruhnya adalah kebiasaan olahraga dan variabel yang paling kecil pengaruhnya adalah status gizi. Menurut nilai OR masing-masing variabel, maka dapat disimpulkan bahwa:

a. Pegawai yang memiliki status gizi lebih berpeluang sebesar 2,4 kali untuk mengalami prediabetes dibandingkan pegawai yang memiliki status gizi normal setelah dikontrol dengan perilaku merokok dan kebiasaan olahraga.

b. Pegawai yang tidak memiliki perilaku merokok berpeluang sebesar 0,3 kali untuk mencegah prediabetes dibandingkan pegawai yang memiliki perilaku merokok setelah dikontrol dengan status gizi dan kebiasaan olahraga.

c. Pegawai yang memiliki kebiasaan olahraga $<3$ hari perminggu berpeluang sebesar 4 kali untuk mengalami prediabetes dibandingkan pegawai yang memiliki kebiasaan olahraga $\geq 3$ hari perminggu setelah dikontrol dengan status gizi dan perilaku merokok.

Ketiga variabel tersebut dapat dibuat menjadi suatu model persamaan garis regresi logistik (Z) sebagai berikut:

$Z_{\text {prodiabetes }}=-0,018+0.858_{\text {status gial }}-0,947_{\text {periliku merokok }}+1,389_{\text {kebiassan olahraga }}$

\section{Pembahasan}

Hasil penelitian menunjukkan bahwa 21,9\% pegawai di Institusi Pendidikan Kesehatan X Kota Jambi mengalami prediabetes. Hal ini sejalan dengan penelitian Soewondo dan Pramono (2011) yang menemukan proporsi prediabetes pada umur dewasa menengah sebesar 43,8\%. Penelitian Sulistiowati dan Sihombing (2018) menemukan prediabetes yang terjadi sebesar 24,6\%. Begitu pula dengan penelitian Noventi, Rusdianingseh, dan Khafid (2019) yang memperoleh prevalensi prediabetes dari hasil pemeriksaan GDA di wilayah pegunungan sebesar $83,3 \%$, pesisir $43,4 \%$, perkotaan $73,4 \%$.

ADA (2019) menyatakan bahwa prediabetes adalah kadar gula darah yang lebih tinggi dari biasanya tetapi belum cukup tinggi untuk didiagnosis sebagai diabetes. Umumnya, sebelum orang mengidap diabetes tipe 2, mereka hampir selalu menderita prediabetes.

Prediabetes disebabkan oleh resistensi insulin dan insufisiensi sekresi insulin karena proses penuaan. Faktor risiko prediabetes adalah kondisi metabolik; gaya hidup (rendah serat, kurang aktivitas, merokok); dan demografi (Drabkin dan Smitherman, 2011). Bauch (2016) menyatakan ada beberapa faktor risiko dari prediabetes, antara lain: umur $\geq 45$ tahun, genetik, kelebihan berat badan dengan BMI > 25, kurang melakukan aktivitas fisik, dan riwayat diabetes gestasional.

Berdasarkan hasil penelitian ini, dari enam faktor yang diteliti, terdapat 3 faktor yang tidak memiliki hubungan dengan kejadian prediabetes, antara lain: umur, genetik, dan komposisi keluarga. Hal ini tidak sesuai dengan penelitian-penelitian yang lain. Penelitian Sulistiowati dan Sihombing (2018) menemukan proporsi prediabetes dan terjadinya DM tipe 2 di Bogor Tengah dalam pengamatan 2 tahun, meningkat dengan bertambahnya umur dan dipengaruhi oleh obesitas sentral, hipertensi, hipertrigliserida.

Penelitian Paramita dan Lestari (2019) menunjukkan bahwa riwayat keluarga memberikan risiko enam kali lebih besar kepada keturunannya untuk menderita DM tipe 2 ( $\mathrm{p}<0,05, \mathrm{OR}=6,27$, IK 95\%=1,9520,21). Sovia, Rekawati, dan Kuntarti (2013) dalam penelitiannya menemukan ada hubungan antara tipe keluarga $(\mathrm{OR}=2,070 ; 95 \%$ CI 0,957-4,478).

Perbedaan hasil penelitian ini dengan penelitian terdahulu dapat disebabkan oleh beberapa faktor. Pertama, sebagian besar responden yang terlibat dalam penelitian ini tidak termasuk dalam kategori umur berisiko terkena prediabetes (berumur kurang dari 45 tahun). Menurut Sherwood (2004), perubahan biologis berupa proses menua (aging) biasanya terjadi pada masa dewasa pertengahan produksi enzim-enzim seperti; protein kinase, glikogen kinase, glukokinase yang dapat mengikat insulin mulai terganggu, sehingga akibatnya glukosa di dalam hati dan otot kembali beredar ke dalam 
darah. Perubahan pada permeabilitas sel dan respon inti sel terhadap hormon insulin, yang mengakibatkan glukosa tidak dapat masuk ke dalam sel merupakan salah satu dampak dari proses menua (Darmojo, 2009). Sehingga terjadi hiperglikemia yaitu

Kedua, faktor risiko prediabetes yang tidak dapat dimodifikasi adalah faktor genetik dan umur. Akan tetapi hanya sebesar 5\% seseorang terkena prediabetes/ diabetes yang disebabkan oleh faktor risiko genetik dan umur. Gaya hidup yang tidak sehat merupakan faktor penyebab terbanyak dari prediabetes/ diabetes (ADA, 2019). Menurut teori Hendrik L. Blum (1974) dalam Notoatmodjo (2010), terdapat empat faktor yang mempengaruhi kesehatan individu, antara lain: genetik (10\%), perilaku (30\%), lingkungan $(40 \%)$, dan pelayanan kesehatan $(20 \%)$. Faktor genetik memberikan pengaruh yang paling kecil dibandingkan faktor perilaku dan lingkungan yang mempunyai pengaruh yang sangat besar terhadap status kesehatan seseorang.

Ketiga, komposisi keluarga atau tipe keluarga tidak mempengaruhi kejadian prediabetes karena sebagian besar responden memiliki tipe keluarga kecil. Menurut Friedman, Bowden, dan Jones (2010), jumlah anggota keluarga yang tinggal dalam satu rumah akan mempengaruhi kemampuan keluarga dalam pemeliharaan kesehatan anggotanya. Kaakinen, Duff, Coehlo, dan Hanson (2010) menyatakan bahwa struktur keluarga (komposisi dan tipe keluarga) mempengaruhi pelaksanaan peran dan fungsi keluarga dalam kehidupan sehari-hari.

Penulis berpendapat bahwa keluarga yang mempunyai anggota keluarga yang sedikit lebih bebas dalam menggunakan keuangan keluarga untuk kebutuhan sehari-hari dan kesenangan keluarga, sehingga kadang-kadang pemenuhan kebutuhan keluarga melebihi yang seharusnya, khususnya dalam kebutuhan nutrisi. Akan tetapi, jumlah anggota keluarga yang kecil membuat keluarga lebih mempunyai waktu dan dana dalam melakukan perawatan dan pemeriksaan kesehatan secara berkala dengan lebih baik.

Penelitian ini juga menunjukkan bahwa terdapat 3 faktor yang mempengaruhi terjadinya prediabetes, yaitu: kebiasaan olahraga, perilaku merokok, dan status gizi. Ketiga faktor tersebut merupakan faktor gaya hidup seseorang. Teori H. L. Blum menjelaskan bahwa faktor gaya hidup (perilaku) memiliki pengaruh yang besar terhadap kesehatan individu, yaitu sebesar 30\% (Rokom, 2019). Stanhope dan Lancaster (2004) mengidentifikasi faktor-faktor risiko kesehatan, antara lain: risiko biologis dan usia, risiko lingkungan (sosial ekonomi), risiko perilaku (gaya hidup), dan risiko kejadian dalam hidup.

Hasil penelitian ini sejalan dengan beberapa penelitian terdahulu. Penelitian Sari dan Purnama (2019) menunjukkan bahwa ada hubungan aktivitas fisik terhadap kejadian diabetes melitus $(\mathrm{p}=0.009$, $\mathrm{OR}=11.000$ ). Penelitian Sukenty, Shaluhiyah, dan Suryoputro (2018) memperoleh hasil bahwa terdapat hubungan kebiasaan merokok atau perokok pasif dengan status prediabetes $(\mathrm{p}=0.046, \mathrm{OR}=2,493)$. Liberty (2016) dalam penelitiannya menemukan bahwa obesitas memiliki hubungan yang signifikan dengan kejadian prediabetes $(\mathrm{OR}=2,63, \mathrm{CI} 95 \%=1,36-5,35, \mathrm{p}=0,05)$.

Canter (2019) dan Hilton (2018) menjelaskan bahwa perbaikan gaya hidup akan dapat menghentikan prediabetes berkembang menjadi diabetes, antara lain dengan perubahan pola makan, mengurangi kelebihan berat badan, dan aktif berolahraga. Olahraga dapat dilakukan 150 menit perminggu atau 30 menit setiap hari selama lima hari dalam seminggu. Jenis olahraga yang dilakukan adalah latihan aerobik (berjalan, berenang, menari) dan latihan kekuatan (angkat beban, push-up, pull-up) (Robinson, 2018).

Robinson (2018) menyatakan bahwa perokok $30 \%-40 \%$ lebih berisiko diabetes tipe 2 dibandingkan bukan perokok. Dan penderita diabetes yang masih merokok, kemungkinan akan menunjukkan gejala yang lebih buruk dan gula darah lebih sulit dikendalikan. Beberapa cara menghindari keinginan merokok, antara lain: 1) hindari berkumpul dengan teman - teman yang sedang merokok, 2) yakin diri bahwa rokok bukan satusatunya sarana pergaulan, 3) jangan malu mengatakan bahwa diri kita bukan perokok, 4) perbanyak mencari informasi tentang bahaya rokok, 5) hindari sesuatu yang terkait tentang rokok (sponsor, iklan, poster, rokok gratis), dan 6) lakukan hal-hal positif lainnya, seperti olahraga, membaca, berkebun, atau hobi lain yang menyehatkan (Direktorat P2PTM Kemenkes RI, 2019).

Status gizi dipengaruhi oleh pola makan individu sehari-hari. Perencanaan dan pengelolaan diet yang baik untuk mencegah diabetes adalah makan makanan gizi seimbang dengan komposisi energi dari karbohidrat 45$65 \%$, protein $10-15 \%$ dan lemak $20-25 \%$ serta dengan jadwal teratur, jumlah sesuai dengan kebutuhan tubuh dan jenis makanan yang bervariasi (Direktoral P2PTM Kemenkes RI, 2019). Menurut Scalpi (2011), pola makan yang baik dalam mengontrol berat badan dan mencegah pradiabetes adalah makan dengan interval yang teratur; makan bijian utuh, sayur, dan buah; kurangi porsi makan 25-30\%; makan karbohidrat komplek (seperti kentang, jagung) daripada karbohidrat sederhana (seperti gula, jus); ganti cemilan/ snack dengan buah dan sayuran; dan perbanyak minum air putih setiap harinya. Sementara itu, Marlow (2012) menjelaskan diet yang sehat meliputi: makan makanan yang tinggi serat seperti sayur, buah, kacang-kacangan sebanyak 20-30 gram perhari; sayur dan buah yang dikonsumsi berwarna hijau, orange, atau kuning seperti brokoli, wortel, semangka, blewah, jeruk; kurangi minum bersoda (cukup dikonsumsi sebanyak 12 ons sekali sehari $=160$ kalori, dan dapat ditambah 16 pons); pilih makanan yang tidak berlemak dan hentikan lemak jenuh; makan lebih banyak ikan dan kacang-kacangan; jaga porsi makan sedang terutama untuk makanan tinggi kalori; konsumsi kolesterol < $300 \mathrm{mg} /$ hari; hindari 
pengulangan jenis makanan setiap hari; dapatkan asupan vitamin dan mineral langsung dari makanan; pastikan asupan makanan seimbang dengan haluaran; dan ganti snack dengan buah, sayur, kacang-kacangan, atau kismis; serta kurangi konsumsi alkohol.

Berdasarkan hasil dan pembahasan tersebut diatas, maka penulis berpendapat bahwa dalam penanggulangan prediabetes di masyarakat, perawat komunitas mempunyai peranan untuk memberikan promosi kesehatan dengan menggunakan 3 tingkat preventif, antara lain: preventif primer berupa promosi kesehatan dan proteksi spesifik; preventif sekunder yang terdiri dari diagnosis awal, pengobatan yang tepat, dan pembatasan kecacatan; dan preventif tersier yang bertujuan untuk pemulihan dan rehabilitasi. Selain itu, perlu ditingkatkan kegiatan promosi kesehatan pada kelompok usia dewasa dan mengaktifkan posbindu di fasilitas kantor atau institusi pendidikan agar kesehatan pegawai/pekerja terpantau dan mereka lebih peduli terhadap kesehatannya sejak dini.

\section{SIMPULAN}

Kejadian prediabetes pada pegawai di Institusi Pendidikan Kesehatan X Kota Jambi sebesar 21,9\%. Faktor yang paling dominan mempengaruhi terjadinya prediabetes tersebut adalah status gizi, perilaku merokok, dan kebiasaan olahraga.

Hasil penelitian ini memberikan rekomendasi bahwa pentingnya melakukan pemeriksaan kesehatan, khususnya pada usia > 45 tahun keatas, karena pada usia tersebut sudah mulai terjadi proses penuaan dalam tubuh. Dengan pemeriksaan tersebut, maka kondisi kesehatan seseorang akan terkontrol. Selain itu, perlu juga melakukan perubahan gaya hidup menjadi perilaku sehat dengan melaksanakan Gerakan Masyarakat Sehat (Germas) dalam kehidupan sehari-hari.

\section{DAFTAR PUSTAKA}

Abraham, T.M., dan Fox, C.S. (2013). Implications of Rising Prediabetes Prevalence. Diunduh dari https://care.diabetes journals. org/content/36/8/2139 pada tanggal 12 Desember 2019.

ADA. (2019). Prediabetes: With Prediabetes, Action is The Best Medicine. Diunduh dari https://www.diabetes.org/diabetes-risk /prediabetes pada tanggal 12 Desember 2019.

Balitbangkes Kemenkes RI. (2013). Laporan Hasil Riset Kesehatan Dasar 2013. Jakarta: Kemenkes RI.

Balitbangkes Kemenkes RI. (2018). Laporan Hasil Riset Kesehatan Dasar 2018. Jakarta: Kemenkes RI.

Basina, M, Higuera, V, dan Huffman, B. (2018). What is Prediabetes. Diabetes.co.uk. Diunduh dari https://www.healthline.com /health/type-2diabetes/what-is-prediabetes pada tanggal 9 Agustus 2019.
Bauch, A. (2016). I've Been Diagnosed With Prediabetes. What Does That Mean? Diunduh dari https://www.mayoclinic healthsystem.org/ pada tanggal 13 Januari 2020

Canter. (2019). The Exercise Effect And Prediabetes. Diunduh dari https://www. gulfbend.org/poc pada tanggal 12 Desember 2019.

CDC. (2019). About Prediabetes and Type 2 Diabetes. Diunduh dari https://www.cdc. gov/diabetes/prevention/aboutprediabetes.html pada tanggal 13 Januari 2020.

CDC. (2020). The Surprising Truth About Prediabetes. Diunduh dari https://www. cdc.gov/diabetes/library/features/truth-aboutprediabetes.html pada tanggal 13 Januari 2020.

Darmojo. (2009). Buku Ajar Geriatri. Jakarta: FKUI.

Direktorat P2PTM Kemenkes RI. (2019). Buku Pintar Kader Posbindu. Jakarta: Kemenkes RI.

Drabkin, A. \& Smitherman, R.K. (2011). Prediabetes. The Clinical Advisor. November 2011: 78-88. Diunduh dari www.ClinicalAdvisor.com padatanggal 1 Oktober 2012.

Friedman, Bowden, \& Jones (2010). Family Nursing: Research, Theory, And Practice. Fifth Edition. New Jersey: Prentice Hall.

Greene, B., Merendino, J.J., \& Jibrin, J. (2009). The Best Life Guide to ManagingDiabetes and PreDiabetes. New York: Simon \& Schuster.

Hilton, C. (2018). Preventing Type 2 Diabetes in People with Prediabetes: Do Diet and Exercise Work? Diunduh dari https://www.evidentlycochrane.net/preventingtype-2-diabetes-people-with-prediabetes-do-dietand-exercise-work/ pada tanggal 12 Desember 2019.

Kaakinen, Duff, Coehlo, \& Hanson (2010). Family Health Care Nursing: Theory, Practice And Research. Fourth Edition. Philadelphia: F.A.Davis Company.

Leontis, L.M. dan Fischl, A.H. (2020). What Is Prediabetes? Here's What You Need to Know. Endocrine Web. Diunduh dari https://www.endocrineweb.com/conditions/prediabetes/pre-diabetes pada tanggal 10 Agustus 2020.

Liberty, I. A. (2016). Hubungan Obesitas dengan Kejadian Prediabetes pada Wanita Usia Produktif. Jurnal Kedokteran dan Kesehatan, Volume 3, No. 2, April 2016: 108-113. Diunduh dari https://ejournal.

unsri.ac.id/index.php/jkk/article/download/5161/2 787 pada tanggal 12 Desember 2019.

Marlow, S. (2012). The Rise in Prediabetes and the Threat of Insulin Resistance and Hyperglycemia. USA: Sands Publishing.

Mayo Clinic Staff. (2020). Prediabetes. Diunduh dari https://www.mayoclinic. 
conditions/prediabetes/symptoms-causes/ syc20355278 pada tanggal 6 Maret 2020

NDSS. (2020). Prediabetes. Diunduh dari https://www.diabetesaustralia.com.au/pre-diabetes pada tanggal 3 Maret 2020.

Notoatmodjo, S. 2010. Promosi Kesehatan: Teori \& Aplikasi. Edisi Revisi 2010. Jakarta: Rineka Cipta.

Noventi, I., Rusdianingseh, dan Khafid, M. (2019). Prevalensi, Karakteristik dan Faktor Resiko Prediabetes di Wilayah Pesisir, Pegunungan dan Perkotaan. Jurnal Ners dan Kebidanan, Vol.6, No.3, Desember 2019, hlm. 371-381.

Paramita, D.P. Dan Lestari, A.W.W. (2019). Pengaruh Riwayat Keluarga Terhadap Kadar Glukosa Darah Pada Dewasa Muda Keturunan Pertama Dari Penderita Diabetes Mellitus Tipe 2 di Denpasar Selatan. E-JURNAL MEDIKA, Vol. 8 No.1, Januari 2019. Diunduh dari https://ojs.unud.ac.id/ index.php/eum pada tanggal 12 Desember 2019.

Robinson, J. (2018). Prediabetes: You Can Turn It Around. Diunduh dari https://www.webmd .com/diabetes/ pada tanggal 12 Desember 2019.

Rokom. (2019). Derajat Kesehatan 40\% Dipengaruhi Lingkungan. Diunduh dari http://sehatnegeriku.kemkes.go.id pada tanggal 12 Desember 2019.

Sari, N. dan Purnama A. (2019). Aktifitas Fisik dan Hubungannya dengan Kejadian Diabetes Melitus. Jurnal Kesehatan. Vol.1 No.2. Oktober 2019. Halaman 368-381. Diunduh dari http://jurnal.fkmumi.ac.id /index.php/woh/article/view/woh2408 pada tanggal 3 Januari 2020.

Scalpi, G. (2011). The Everything Guide to Managing and Reversing Pre-Diabetes: Your Complete Plan For Preventing The Onset of Diabetes. USA: F+WMedia, Inc.

Sherwood, L. (2004). Human Physiology: From Cells To Systems. Fifth Edition.USA: Thomson Brooks/ Cole.

Soewondo, P. \& Pramono, L.A. (2011). Prevalence, Characteristics, and Predictors Of Pre-diabetes In Indonesia. Medical Journal Indonesia, 20 (4): 283-294. Diunduh dari www.google.com pada tanggal 30 September 2013.

Sovia, Rekawati, E., dan Kuntarti. (2013). Kejadian Pradiabetes Pada Usia Dewasa Menengah Berdasarkan Karakteristik dan Perilaku Perawatan Kesehatan Keluarga. Jurnal Keperawatan Indonesia. Vol 16, No 3 (2013). Diunduh dari http://jki.ui.ac.id/index.php/jki/article/ view/325 pada tanggal 12 Desember 2019.

Stanhope, M. \& Lancaster, J. (2004). Community And Public Health Nursing, $6^{\text {th }}$ ed. St Louis: Mosby

Sukenty, N.T., Shaluhiyah, Z., dan Suryoputro, A. (2018). Faktor Perilaku dan Gaya Hidup yang Mempengaruhi Status Prediabetes Pasien
Puskesmas Pati II. Jurnal Promosi Kesehatan Indonesia Vol.13/ No.2/ Agustus 2018. Diunduh dari https://ejournal.undip.ac.id/index.php/jpki /article/viewFile/20250/14004 pada tanggal 12 Desember 2019.

Sulistiowati, E. dan Sihombing, M. (2018). Perkembangan Diabetes Melitus Tipe 2 dari Prediabetes di Bogor, Jawa Barat. Jurnal Penelitian dan Pengembangan Pelayanan Kesehatan, Vol. 2, No. 1, April 2018. Diunduh dari https://ejournal2. litbang.kemkes.go.id/index.php/jpppk/article/dow nload/53/819 pada tanggal 6 Maret 2020. 